\title{
Evaluation Research on the Positioning Decision for Senior Real Estate Project Based on SEM model
}

\author{
Yijing Peng \\ College of Management \\ Wuhan University of Science and Technology \\ Hubei, China \\ 19963595@qq.com
}

\begin{abstract}
Under the background of the increasing aging population, developers have been actively investing in the development of senior housing real estate projects, while the merits of the earlier stage positioning decision on the senior housing real estate projects would direct impact the later operation. Targeting on this problem, the evaluation model of the positioning structural equation of the pension project has been constructed in the four perspectives of the macroscopic and location environment, the development enterprise, the user demand in the project and the target customers, and the 2nd order verification on this model based on the reliable data research has been conducted, results show that the aging degree program radiation area, the financial strength of the enterprise, the basic facilities and project services as well as the ability to pay should first consideration, thus to provides a new idea for the positioning evaluation of the pension project.
\end{abstract}

Keywords-Senior Real Estate; Project Positioning; Structural Equation; Evaluation Index

\section{INTRODUCTION}

Population aging has become the increasingly concerned issue of social focus, as the data shows, the elderly population over 65 years old in China has exceeded the international aging standard by the end of 2015 , accounting for $10.5 \%$ of the total population, it's expected that the elderly population will increase to 260 million by 2020; and China's elderly population would exceed the young population for the first time in 2030; the elderly population would reach 400 million by 2050 and keep the scale of 400 million people for a long time. [1] According to the domestic and foreign literature, the senior housing real estate is the old-age housing project with both social and economic significance to the developers; for the elderly households, the senior housing real estate is the carrier with multi-service functions including direct care and medical health care, and it's a kind of living option with both innovation and long-term effectiveness. As Lawton (1975) [2] points out, both the planning and design of the pension community and the supporting facilities should pay attention to the characteristics of the elderly people, and the operation of the project requires relevant training. After investigation, the three scholars of Karen M. Gilbler, Euehun Lee and George P. Moschis (1998) [3] have found that well-educated elderly people are more willing to stay in large-scale pension communities after retirement. Before the occupancy, elderly people would investigate whether the pension project has the functions of medical care, private care, shopping, convenient transportation, space for activities, social interaction, etc., and they tend to stay in the pension communities with company functions and facilities. Li Xingyun (2010) [4] assumes that the development China's pension industry is relatively slow and is far from the actual pension needs, on the other hand, China's population aging rate is developing too fast, while the level of economic development is not enough to meet the demand of the aging population.

Therefore, a comprehensive pension policy should be developed in China to support the development of pension industry from real estate developers. Zhou Yanmin (2012) [5] points out that issues of blind pursuit for high-end and the homogenization of planning and operation exist in the positioning of the planning, site selection, functional support and size of the current pension communities in China, and the appropriate recommendations are proposed. Sha Guohua (2015) [6] points out that the elderly's demand for senior housing real estate is affected by factors such as age, physical condition, occupation and income, while most of them are potential demands, so the development companies should make the potential demands explicit with effective measures. Lei Long (2016) [7] points out that the key to the success or failure of senior housing real estate projects lies in the correct marketing and customer positioning.

Targeting on the existing problems in development positioning of the senior housing real estate projects in China, this paper constructs the evaluation system of the senior housing real estate projects and calculate the weight of the indicators with the structural equation model.

\section{CONSTRUCTION OF THE EVALUATION INDEX OF THE SENIOR HOUSING REAL Estate PROJECT POSITIONING}

Based on the researches of project positioning by various scholars and combining the existing problems of the senior housing real estate project as well as experts' advice, the index system of the decision-making evaluation of the senior housing real estate project has been established in this paper, as refer with: Table 1. 
TABLE I. THE INDEX OF THE POSITIONING EVALUATION OF THE SENIOR REAL ESTATE

\begin{tabular}{|c|c|}
\hline Latent variable & Observational variables \\
\hline $\begin{array}{c}\text { Macro and location } \\
\text { environmental factors } \\
\text { MA }\end{array}$ & $\begin{array}{l}\text { State support for senior housing policy } \\
\mathrm{MA}_{1} \\
\text { location Government's policy support } \mathrm{MA}_{2} \\
\text { location Financial institutions' support } \mathrm{MA}_{3} \\
\text { radiation area aging degree } \mathrm{MA}_{4} \\
\text { surrounding influencing degree } \mathrm{MA}_{5} \\
\text { surrounding infrastructure MA6 } \\
\text { Project target market's effective demand } \\
\mathrm{MA}_{7}\end{array}$ \\
\hline $\begin{array}{l}\text { Develop enterprise factors } \\
\text { DC }\end{array}$ & $\begin{array}{l}\text { Corporate reputation and brand influence } \\
\text { DC }_{1} \\
\text { Financial strength of the Corporate } \mathrm{DC}_{2} \\
\text { Financing capacity of the Corporate } \mathrm{DC}_{3} \\
\text { Operating level of senior housing real } \\
\text { estate project of the Corporate } \mathrm{DC}_{4} \\
\text { Matching degree of the corporate strategic } \\
\text { objectives and senior housing real estate } \\
\text { project } \mathrm{DC}_{5}\end{array}$ \\
\hline $\begin{array}{c}\text { Customer demand factors for } \\
\text { senior housing real estate } \\
\text { project } \\
\text { SPCD }\end{array}$ & $\begin{array}{l}\text { Differentiation between the project and } \\
\text { similar projects SPCD } \\
\text { Project's overall layout planning and } \\
{\text { moving line design } \mathrm{SPCD}_{2}} \\
\text { Project Construction Planning and Design } \\
\text { SPCD }_{3} \\
\text { Project Aging and Accessibility Facility } \\
\text { Planning SPCD } \\
\text { Completion of the project supporting } \\
\text { facilities SPCD } \\
\text { Project Pension Intelligent Equipment and } \\
\text { Facilities SPCD } \\
\text { Valid combination of related pension } \\
\text { industry SPCD } \\
\text { Business model selection SPCD } \\
\text { Expected Calculation on the Project Input } \\
\text { \&Output SPCD } \\
\text { Service and Operations Management } \\
\text { SPCD }_{10}\end{array}$ \\
\hline $\begin{array}{c}\text { Target customer base } \\
\text { TC }\end{array}$ & $\begin{array}{l}\text { Age structure of target customer groups } \mathrm{TC}_{1} \\
\text { Health composition ratio groups } \mathrm{TC}_{2} \\
\text { Payment capacity } \mathrm{TC}_{3} \\
\text { Cognition accuracy of the pension demand } \\
\text { of target customer groups } \mathrm{TC}_{4}\end{array}$ \\
\hline
\end{tabular}

\section{EVALUATION RESEARCH ON THE POSITIONING DECISION FOR THE SENIOR HOUSING REAL ESTATE STRUCTURAL EQUATION MODEL}

\section{A. Collect the Data through Questionnaires}

The questionnaire is designed according to the abovementioned constructed evaluation index system of the senior housing real estate project; the questionnaire is implemented based on the Likert 7 level scale. Prior to the survey, advice from a number of research experts with rich experience in senior housing real estate project research was consulted, with the research objects of the practitioners with experience in senior housing real estate project coming from developers, design organs and construction units, meanwhile pension project customers (or potential customers) are also investigated, who are mainly the residents already purchasing the pension projects and partial residents of public pension institutions. The questionnaire filling could correctly reflect the importance of the positioning evaluation index of investing in senior housing real estate projects. In this survey a total of 300 questionnaires are issued, and 284 copies are effectively recovered after screening, and the recovery rate is 95\%, meeting the requirement on the structural equation sample capacity. [8]

\section{B. Reliability and validity Test on the Questionnaire}

TABLE II. THE COEFFICIENT OF CRONBACH'S ALPHA

\begin{tabular}{|c|c|c|}
\hline Latent variable & $\begin{array}{c}\text { Number of observable } \\
\text { variables }\end{array}$ & $\begin{array}{c}\text { Cronbach's } \\
\text { Alpha }\end{array}$ \\
\hline $\begin{array}{c}\text { Macroscopic and location } \\
\text { environmental factor }\end{array}$ & 7 & 0.920 \\
\hline $\begin{array}{c}\text { Factors for developing } \\
\text { enterprises }\end{array}$ & 5 & 0.924 \\
\hline $\begin{array}{c}\text { Customer demand factors for } \\
\text { senior housing real estate } \\
\text { project }\end{array}$ & 10 & 0.945 \\
\hline $\begin{array}{c}\text { Factors for target customer } \\
\text { base }\end{array}$ & 4 & 0.891 \\
\hline
\end{tabular}

As Table 2 shows, the dimension reliability coefficient of each variable is greater than 0.7 , the total correlation of the corrected items is greater than 0.5 , and the Cronbach's alpha value of the deleted item is not greater than the coefficient of the entire dimension reliability, indicating the reliability of the dimension meets the requirements. In present, the paper extracts the factor based on that the eigenvalue is greater than 1 , the cumulative square sum is $70.937 \%$ and greater than $60 \%$, indicating that the scale has a good validity of construction.

\section{C. $2^{\text {nd }}$ Order verification factor Analysis on the structural Equation}

According to the previous theoretical analysis, the model of 2nd order verification factor analysis is established with amos21 in this paper. According to the revised indicators of the structural equation, add the co-denaturation between e2 and e3, e13 and e14, e13 and e15, e17 and e22 as well as e20 and e22, thus to reduce the chi-square value of the model, it is found that the fitting index of the model is significantly enhanced and reaches the standard value after the correction, indicating that the model meets the requirements, as shown in Fig. 1. 

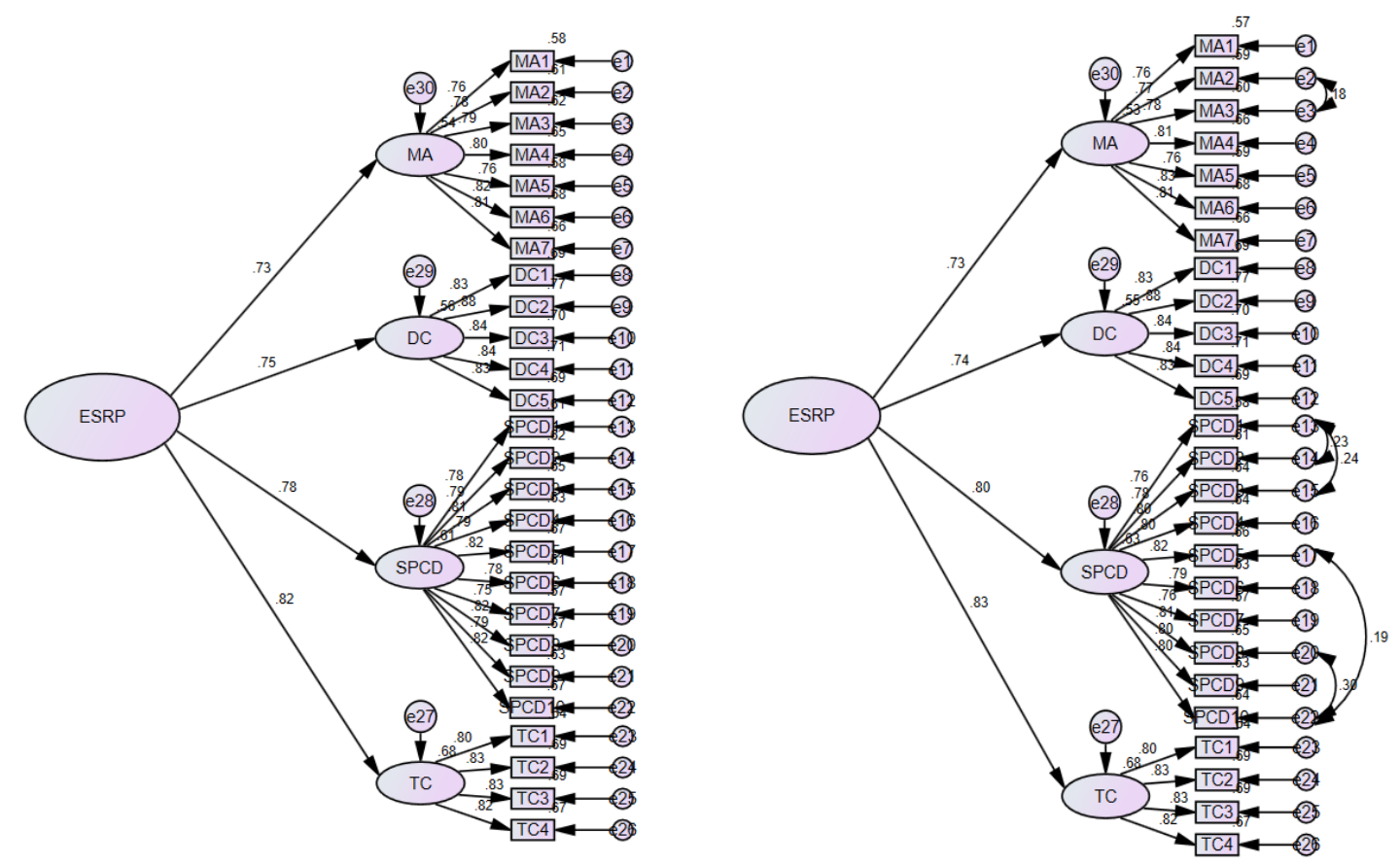

Fig. 1. Model before modification and Modified model

\section{Determination on the Indicator Weight}

Weights of the 1st order variable and 2nd order variable are determined based on the normal path coefficients of the 2nd order confirmatory factor analysis in this paper. Take MA1 in macroscopic and location environmental factor as the (1); Weights of the 1st order variable and 2nd order variable are calculated through the calculation, shown in the following Table 3.

$$
\text { MA } 1 \text { Weight }=\frac{M A_{1}}{\sum_{i=1}^{5} M A_{i}} .
$$

TABLE III. 1ST INDEXES AND 2ND INDEXES WEIGHTS

\begin{tabular}{|c|c|c|c|}
\hline $1^{\text {st }}$ Indexes & Weight & $2^{\text {nd }}$ Indexes & Weight \\
\hline \multirow{7}{*}{ Macro and location environmental factors } & \multirow{7}{*}{0.236} & $\mathrm{MA}_{1}$ & 0.137 \\
\hline & & $\mathrm{MA}_{2}$ & 0.139 \\
\hline & & $\mathrm{MA}_{3}$ & 0.141 \\
\hline & & $\mathrm{MA}_{4}$ & 0.147 \\
\hline & & $\mathrm{MA}_{5}$ & 0.139 \\
\hline & & $\mathrm{MA}_{6}$ & 0.150 \\
\hline & & $\mathrm{MA}_{7}$ & 0.148 \\
\hline \multirow{5}{*}{ Develop enterprise factors } & \multirow{5}{*}{0.241} & $\mathrm{DC}_{1}$ & 0.201 \\
\hline & & $\mathrm{DC}_{2}$ & 0.213 \\
\hline & & $\mathrm{DC}_{3}$ & 0.202 \\
\hline & & $\mathrm{DC}_{4}$ & 0.204 \\
\hline & & $\mathrm{DC}_{5}$ & 0.200 \\
\hline \multirow{10}{*}{ Customer demand factors for senior housing real estate project } & \multirow{10}{*}{0.257} & $\mathrm{SPCD}_{1}$ & 0.097 \\
\hline & & $\mathrm{SPCD}_{2}$ & 0.099 \\
\hline & & $\mathrm{SPCD}_{3}$ & 0.101 \\
\hline & & $\mathrm{SPCD}_{4}$ & 0.101 \\
\hline & & $\mathrm{SPCD}_{5}$ & 0.103 \\
\hline & & $\mathrm{SPCD}_{6}$ & 0.100 \\
\hline & & $\mathrm{SPCD}_{7}$ & 0.096 \\
\hline & & $\mathrm{SPCD}_{8}$ & 0.102 \\
\hline & & $\mathrm{SPCD}_{9}$ & 0.101 \\
\hline & & $\mathrm{SPCD}_{10}$ & 0.101 \\
\hline \multirow{4}{*}{ Target customer base } & \multirow{4}{*}{0.267} & $\mathrm{TC}_{1}$ & 0.244 \\
\hline & & $\mathrm{TC}_{2}$ & 0.254 \\
\hline & & $\mathrm{TC}_{3}$ & 0.253 \\
\hline & & $\mathrm{TC}_{4}$ & 0.249 \\
\hline
\end{tabular}


As the Table 3 above shows, the target customer base has the highest weight in the 1st order variable, followed by the senior housing real estate project, and the macroscopic and location environmental factor has lowest weight; MA6, MA4 and MA7 has the highest weight in the macroscopic and location environmental factor; DC2 has the high weight in the developing enterprises; SPCD5 and SPCD8 have the high weight in the senior housing real estate project; and TC2 has the high weight in the target customer base.

\section{CONCLUSIONS}

In the perspective of developing enterprises, this paper establishes the positioning evaluation index system of the senior housing real estate project, relevant questionnaire has been designed in four dimensions of macroscopic and location environment, the factor of developing enterprises, senior housing real estate project user needs and the target customer base, and the weights of each evaluation index are calculated according to the actual survey data. The optimal structural equation model is finally obtained via the model correction. This method could make a comprehensive, reasonable and objective evaluation of the senior housing real estate project positioning, Macro, thus to provides a new idea for the evaluation of the senior housing real estate project. Meanwhile, conclusions could be given: factors influencing the senior housing real estate project are target customer base, senior housing real estate project user needs, the factor of developing enterprises and macroscopic and location environment successively from large too small. In the market economy environment, especially "for whom to serve" and "what kinds of service to provide" only provides diversified and more suitable services to the society.

\section{REFERENCES}

[1] National Committee of the Elderly People, the future aging population in China would account for $1 / 4$ of the world and the pension industry will break out for growth [OL] .2016 (11). http://www.cncaprc.gov.cn/contents/16/177571.html (In Chinese)

[2] Lawton M, Powell. Planning and managing housing for the elderly [M]. New York. Wiley.1975.

[3] KM Gibler, GP Moschis, E Lee. Planning to move to retirement housing [J]Financial Services Review, 1998, 7(4), pp.291-300.

[4] Li Xueyun. A brief discussion on the development of the status quo and countermeasures for the senior housing real estate industry [J] Shanghai premises, 2010 (11): pp.28-29. (In Chinese)

[5] Zhou Yanmin, Lin Jingyi. The development status and planning principle analysis on China's pension community [J]. Urban Planning 2012 (1): pp.47-51. (In Chinese)

[6] Sha Guohua. Study on the demand willing and influencing factors of the senior housing real estate market under the background of the aging population [J] Financial Development Research, 2015 (11), pp.74-78(In Chinese)

[7] Lei Long. Why senior housing real estate project has weak sales, China Real Estate: the market version, 2016 (10), pp.46-47 (In Chinese)

[8] Wu Minglong. The operation and application of structural equation model Amos [M]. Chongqing: Chongqing University (In Chinese) 